\title{
Interpersonal Communication to Teenagers in Purwokerto, Indonesia
}

\section{Komunikasi Interpersonal kepada Remaja di Purwokerto, Indonesia}

Twi Lia Widiyawati ${ }^{1}$, Dyah Astorini Wulandari ${ }^{2}$

${ }^{1,2}$ Universitas Muhammadiyah Purwokerto, Indonesia

\begin{tabular}{l} 
ARTICLE INFO \\
\hline Article history: \\
DOI: \\
10.30595/pssh.v2i.98 \\
Submitted: \\
July 31, 2021 \\
Accepted: \\
Aug 26, 2021 \\
Published: \\
Sept 24, 2021 \\
\hline
\end{tabular}

\section{Keywords:}

Interpersonal

Communication, Teenagers,

Junior High School

\begin{abstract}
Interpersonal communication is communication made by two or more people that produces a response both verbally and nonverbally. This study aims to describe the interpersonal communication possessed by adolescents in Purwokerto. The participants in this study were active teenagers from one of the private junior high schools in Purwokerto $(n=47)$. The research method used in this study is a quantitative descriptive approach with data collection using the Interpersonal Communication scale and measured using aspects of interpersonal communication Devito (2013), namely: openness, Empathy, supportive attitude, positive attitude, and equality. From the results of the research they have conducted. This shows the level of interpersonal communication in students, with the result that 24 students or $51.7 \%$ of students in Purwokerto have difficulty or difficulty in communicating. In comparison, 23 students, or $48.3 \%$ of students in Purwokerto, have no problem communicating interpersonally. Based on these results, it is expected that educational institutions can explore and provide more stimulus to improve interpersonal communication to students.
\end{abstract}

This work is licensed under a Creative Commons Attribution 4.0 International License.

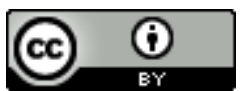

\section{Corresponding Author:}

Twi Lia Widiyawati

Universitas Muhammadiyah Purwokerto, Indonesia

Email: widiyatit93@gmail.com

\section{INTRODUCTION}

Humans are social creatures, which means humans cannot live alone. Therefore, humans need other people around them. Humans need to communicate or interact with other humans (Juliana \& Erdiansyah, 2020). According to Wood and Julia (in Irawan 2017), communication is one of the tools used to interact between individuals; communication also touches all aspects of human life, as a person's daily life will not be separated from communication.

Communication is a social process that occurs and is carried out by two or more people who exchange information and meaning. This is the same as the opinion of Griffin and Moorhead (in Hidayat, 2017). Usman (2013) said that humans in their lives must communicate with each other, which means they need other people and need groups or communities to communicate with each other or interact with each other.

According to Papalia, Olds, \& Feldman (in Widiantari \& Herdiyanto, 2013), the need to have relationships with other people will be high when the individual is at the stage of adolescent development. Adolescence is often referred to as the social period because social relations will become increasingly clear and become very dominant (Paramitasari \& Dewi, 2013). Sakti \& Yulianto (2013) also stated that adolescence is a transition period from children to adults, marked by searching for identity and building self-image in the community. So, teenagers want to get recognition and want to be admired by the community and show their existence.

Adolescents are expected to achieve new and more mature relationships with their peers, both male and female. They are expected to achieve emotional independence, more responsible social behavior (Kusumo \& Jatmika, 2020). According to Widiantari \& Herdiyanto (2013), adolescence is a developmental transition between childhood and adulthood, which involves cognitive, biological, and social development changes. Santrock (in Widiantari \& Herdiyanto, 2013) explains that adolescents are characterized by a demand to achieve independence 
and change in establishing relationships with other individuals in a social context.

But, at this time, teenagers face a problem related to interpersonal communication, where they have difficulty communicating with the surrounding environment. This is also said by Purnomo (in Kusumo \& Jatmika, 2020) that adolescents have difficulty achieving a new and more mature relationship in communicating with others and being able to express their thoughts, feelings, and opinions.

From a preliminary study conducted at a private junior high school in Purwokerto. With a total of 47 respondents. As many as 24 respondents said there were difficulties or obstacles in interpersonal communication, with a percentage of $51.7 \%$, while 23 respondents said there were no obstacles in interpersonal communication with 48.3\%. Constraints experienced by adolescents in interpersonal communication include: when communicating, the interlocutor does not respond well, there is no positive feedback when communicating, feels nervous, does not dare to see the interlocutor, is not confident, is overlooked. This is supported by preliminary study data conducted by Akbar \& Faryansyah (2018) on 145 respondents, which showed that adolescents aged 12-21 years experienced feelings of irritation (11.7\%), feeling uncomfortable (1.4\%), low (6.9\%), and feel ashamed (1.4\%) when the individual gets criticism from other individuals. And experiencing feelings of shame (29\%), nervousness (13.4\%), fear $(4.8 \%)$, and feeling uncomfortable $(1.4 \%)$ when the individual is doing activities that many people see. The following illustrates how important it is for teenagers to feel accepted by their peers, regardless of their gender (Garcia in Akbar \& Faryansyah, 2018).

Based on the above background, the purpose of this study is to describe the interpersonal communication possessed by adolescents in a private junior high school in Purwokerto.

\section{THEORITICAL FRAMEWORK}

Interpersonal communication occurs between connected people or can be interpreted as communication carried out in two or more directions (Devito, 2013). Interpersonal communication is the exchange of messages between one person and another, intentional or not, and can be interpreted by the recipient without any limitation on the number of people involved. in exchange (Darmawan, Silvana, Zaenudin \& effendi, 2019). According to Bungin (in Darmawan, Silvana, Zaenudin \& Effendi, 2019), interpersonal communication is communication between individuals and is personal, which is carried out directly (without media) or indirectly (through media). According to Pontoh (2013), interpersonal communication is a form of interpersonal communication. Interpersonal communication is communication between people face to face, which allows a participant to catch the reactions of others. According to Joseph De Vito (in Kusumo \& Jatmika, 2020), interpersonal communication is sending messages from a person and received by another person or a group of people with effects and direct feedback or, in other words, interpersonal communication is a social process. Irawan (2017) said that communication is needed by everyone, not only for sending or receiving messages but also for meeting the basic needs of individuals, namely giving and getting love, the desire to be part of a group, and the need to influence people.

Mulyana (in Dewi \& Sudhana, 2013) said that interpersonal communication is communication between people face to face and can capture the reactions of others directly, both verbally and nonverbally. Interpersonal communication is also a conversation close to each other, responding to a problem being discussed, both verbally and nonverbally openly, honestly, without prejudice, so mutual understanding occurs (Wiendijarti, 2011). Devito (2013) revealed that interpersonal communication is sending and receiving messages between two people or a small group. Interpersonal communication is understood as feedback that aims to help someone in increasing personal effectiveness and interpersonal effectiveness.

Pontoh (2013) says that interpersonal communication can carry out an instrumental function to influence or persuade others. We can use the five senses to enhance the persuasion of the message that we will communicate to our communicants. Mulyana (in Pontoh, 2013) also said that face-to-face communication could make humans feel more familiar with fellow humans, unlike communication using mass media such as newspapers, television, or any sophisticated technology.

Devito (2013) argues that interpersonal communication consists of 4 aspects: openness, empathy, supportive attitude, and positive attitude. Openness is an attitude that can accept input from others and a willingness to open up to reveal information to others. Empathy is the ability to know what another person is going through at any given moment from the other person's point of view. A supportive attitude is an effective interpersonal relationship, which is a relationship with a supportive attitude, meaning that each party communicating commits to support each other and hold open interactions. A positive attitude when communicating refers to positive things for himself and others and giving praise to others. A positive attitude can be indicated in the form of attitude or behavior. Then the last one is. Equality acknowledges that both parties have interests, and both parties are equally valuable and valuable and need each other.

Then several factors can affect interpersonal communication, according to (Yohana in Juliana \& Erdiansyah, 2020): interpersonal perception, self-concept, interpersonal actress, and interpersonal relationships.

Based on the description above, it can be concluded that interpersonal communication is a communication carried out by two or more people that produces a response both verbally and nonverbally. 


\section{RESEARCH METHODOLOGY}

This method is considered suitable for describing interpersonal communication. Data collection uses an interpersonal communication scale and is measured using aspects of interpersonal communication (Devito, 2013), namely: openness, empathy, supportive attitude, positive attitude, and equality. The participants were 47 private junior high school students in Purwokerto.

The 11 items on the interpersonal communication scale used in this study, such as 1). I always accept suggestions from others. In the first item, as many as $89.4 \%$ said yes, and $10.6 \%$ said no, so it can be concluded that the item shows that most respondents will always accept suggestions from others, 2). You will not hesitate to start a conversation with other people. In this item, many respondents said yes, which is $70 \%$, and the signal said no, so most respondents prefer to start a conversation with other people, 3). Have you ever provided important information about yourself to other people? As many as $66 \%$ said that they provide essential information to others, 4). Do you know what is being experienced or felt by other people? As many as $40 \%$ of the subjects said yes, and $60 \%$ said no, and it can be concluded that there are still many respondents who have less empathy for others, 5). When communicating with other people, do you get a positive response from the other person, such as smiling or nodding your head? Almost $97 \%$ of respondents said yes, and many respondents got a good response when communicating with other people, 6). When you communicate with other people, you get praise from other people; as many as $45 \%$ say yes, and 55\% say no, so it can be concluded that there are still many respondents who get responses that are not following the wishes of the respondents 7). I always pay attention to my interlocutor; $90 \%$ of respondents say yes, 8) when communicating with him. I always have a good attitude towards others, even though I just met $80 \%$ of the respondents said yes, 9). I am aware of the weaknesses and strengths and others; as many as 55\% of respondents said yes, and the rest said no, 10). I am a person who is easy to get along with other people, as much as $60 \%$ said no, meaning that it can be concluded that there are still many respondents who have difficulty getting to know other people, 11). What are your obstacles when communicating with other people, many of the answers that respondents gave such as not confident, awkward, embarrassed, not being listened to by the other person, confused about what to say, not being heard by the other person, rarely being given advice and still a lot more?

\section{RESULTS AND DISCUSSION}

Before explaining interpersonal communication in adolescents, we first describe the profile of the participants in this study: the participants in this study were 47 people. Twenty-five female participants with $55.3 \%$ dominated the categorization of participants based on gender in this study. At the same time, the male participants amounted to 22 people with a percentage of $44.7 \%$.

The categorization of participants in age was dominated by 17 people aged 13 years, 14 years old, 14 people, and 15 years old 14 people. Interpersonal communication can help students' social development; this can be seen from the associations made by students, where students with good interpersonal communication skills will not have difficulty interacting and socializing with their peers. Conversely, suppose students have low interpersonal communication. In that case, they cannot show self-disclosure, empathy, supportive attitude, positive attitude, equality that supports communication, so that close friendships will be challenging to achieve. This will have an impact on difficulty socializing with peers and being more aloof. Of course, this can hinder their social development, in the research conducted (Handayani \& Mayasari, 2019).

The results of 47 respondents showed that as many as 24 students, or $51.7 \%$ of private junior high schools in Purwokerto, had difficulty communicating and had problems communicating. In contrast, 23 students, or $48.3 \%$ of students in Purwokerto, did not. have difficulty communicating interpersonally.

Constraints in interpersonal communication experienced by 24 respondents were the feeling when communicating with the other person did not respond well. There was no positive feedback when communicating, which resulted in the respondent feeling nervous and not daring to look at the interlocutor, not confident, and lacking confidence. Of the 24 respondents who experienced a little difficulty in interpersonal communication, especially in the aspect of equality, namely, equality is an acknowledgment that both parties have interests, are equally valuable and valuable, and need each other. Where in the aspect of equality, there are indicators, namely creating a comfortable atmosphere. However, the 24 respondents still have difficulty creating a friendly atmosphere with other people and create obstacles in communicating with others, such as shyness, insecurity, nervousness. And make students embarrassed to get along with other people.

Apart from the aspect of equality, 24 respondents also experienced difficulties in self-disclosure with others. There are still students who are not honest in expressing what they feel, which raises obstacles in communicating with other people. Darmawan et al. (in Mataputun \& Saud, 2020) explain that the effectiveness of interpersonal communication is strongly influenced by how much openness a teenager interacts with to improve the adolescent's interpersonal relationships and become closer, even though they communicate using social media. Self-disclosure is the key to building interpersonal communication with other individuals (Mataputun \& Saud, 2020).

According to DeVito (2013), interpersonal communication is defined as feedback aimed at helping individuals improve personal effectiveness and interpersonal effectiveness. However, in interpersonal communication, misunderstandings often occur, such as disturbances in communication. According to Wiendijarti (2011), the disorder includes three things, namely physical conditions, psychological disorders, and semantic disorders. Interpersonal communication can be effective or successful if the individuals are ready to accept each

Proceedings homepage: https://conferenceproceedings.ump.ac.id/index.php/pssh/issue/view/7 
other, listen, be open, and be sensitive in reading body language and feedback from other individuals.

Students have good interpersonal communication if they fulfill or show self-disclosure, Empathy, supportive attitude, positive attitude, and Equality. Mataputun \& Saud (2020) explains that students in building a relationship with other people show traits and characters such as openness, share feelings what other people experience, can hear and accept the opinions of others, respect diversity and older, people.

\section{CONCLUSION}

Based on the preliminary study results, it showed that 24 students in Purwokerto had difficulties or problems in communicating. In comparison, 23 students in Purwokerto had no difficulty in communicating interpersonally. And in the communication carried out by the students themselves, there are still many obstacles in communicating interpersonally with other people. Besides that, aspects of interpersonal communication are still not fulfilled during transmission. If the interpersonal communication aspects are fulfilled, there will be no obstacles, and the communication will be good. This, of course, must be a joint evaluation material, both parties with interest in the field of education and other parties related to the importance of interpersonal communication in students or adolescents.

Based on these results, it is hoped that educational institutions will provide an overview to overcome and deal with obstacles in interpersonal communication.

\section{REFERENCES}

Akbar, Z., \& Faryansyah, R. (2018). Pengungkapan Diri Di Media Sosial Ditinjau Dari Kecemasan Sosial Pada Remaja. Ikraith-Humaniora, 2(2), 94-99. https://media.neliti.com/media/publications/226387-pengungkapandiri-di-media-sosial-ditinj-40d239f4.pdf

Darmawan, C., Silvana, H., Zaenudin, H. N., \& Effendi, R. (2019). Pengembangan hubungan interpersonal remaja dalam penggunaan media sosial di Kota Bandung. Jurnal Kajian Komunikasi, $7(2), \quad 159$. https://doi.org/10.24198/jkk.v7i2.21163

Devito, J. A. (2013). The Interpersonal Communication Book (Thirteenth Edition) (K. Bowers \& M. Mashburn (eds.); 13th ed.). Library of Congress Cataloging-in-Publication Data.

Dewi, N. R., \& Sudhana, H. (2013). Hubungan Antara Komunikasi Interpersonal Pasutri dengan Keharmonisan dalam Pernikahan. Jurnal Psikologi Udayana, 1(1), 22-30. https://doi.org/10.24843/jpu.2013.v01.i01.p03

Handayani, S., \& Mayasari, S. (2019). Hubungan Antara Konsep Diri Dengan Komunikasi Interpersonal Pada Siswa The Correlation of Self Concept With Interpersonal Communication. Jurnal Bimbingan Konseling, 7(3), 1-15. http://jurnal.fkip.unila.ac.id/index.php/ALIB/article/view/19039/13573

Hidayat, R. (2017). Perilaku Etis Dosen Dalam Perspektif Efikasi Diri, Kepemimpinan, Dan Komunikasi Interpersonal. Pedagonal : Jurnal Ilmiah Pendidikan, 1(1), 37-44. https://doi.org/10.33751/pedagog.v1i1.220

Irawan, S. (2017). Pengaruh Konsep Diri Terhadap Komunikasi Interpersonal Mahasiswa. Scholaria: Jurnal Pendidikan Dan Kebudayaan, 7(1), 39. https://doi.org/10.24246/j.scholaria.2017.v7.i1.p39-48

Juliana, K., \& Erdiansyah, R. (2020). Pengaruh Konsep Diri dan Self Disclosure Terhadap Kemampuan Komunikasi Interpersonal Mahasiswa. Koneksi, 4(1), 29-35. https://doi.org/10.24912/kn.v4i1.6500

Kusumo, P., \& Jatmika, D. (2020). Adiksi Internet Dan Keterampilan Komunikasi Interpersonal Pada Remaja (Internet Addiction and Interpersonal Communication Skills of Adolescents). Jurnal Psibernetika, 13(1), $20-31$. https://doi.org/10.30813/psibernetika.v13i1.2312

Mataputun, Y., \& Saud, H. (2020). Analisis komunikasi interpersonal dan penyesuaian diri remaja. Jurnal Konseling Dan Pendidikan, 8(1), 32-37.

Paramithasari, P. P., \& Dewi, E. K. (2013). Hubungan Antara Kontrol Diri Dengan Pengungkapan Diri Di Jejaring Sosial Pada Siswa Sma Kesatrian 1 Semarang. Empati, 2(4), 376-385.

Pontoh, W. P. (2013). Peranan Komunikasi Interpersonal Guru Dalam Meningkatkan Pengetahuan Anak. Journal “Acta Diurna,” I(I), 1-11.

Sakti, B. C., \& Yulianto, M. (2013). Penggunaan Media Sosial Instagram Dalam Pembentukan Identitas Diri Remaja. Interaksi-Online, 6(4), 1-12. https://ejournal3.undip.ac.id/index.php/interaksi-online/article/view/21950

Usman, B. (2013). Pengaruh Komunikasi Interpersonal Terhadap Kinerja Pegawai Pada Fakultas Ekonomi Universitas PGRI Palembang. Media Wahana Ekonomika, 10(1), 1-18.

Widiantari, K. S., \& Herdiyanto, Y. K. (2013). Perbedaan Intensitas Komunikasi Melalui Jejaring Sosial antara Tipe Kepribadian Ekstrovert dan Introvert pada Remaja. Jurnal Psikologi Udayana, 1(1), 106-115. https://doi.org/10.24843/jpu.2013.v01.i01.p11

Wiendijarti, I. (2011). Komunikasi Interpersonal Orang Tua dan Anak dalam Pendidikan Seksual. Jurnal Ilmu Komunikasi Terakreditasi, 9(3), 274-292. 